\begin{tabular}{|l|l|l||}
\hline \multicolumn{2}{|c|}{ PublisherInfo } \\
\hline \hline PublisherName & $:$ & BioMed Central \\
\hline \hline PublisherLocation & $:$ & London \\
\hline \hline PublisherImprintName & $:$ & BioMed Central \\
\hline \hline
\end{tabular}

\title{
SNPing away
}

\begin{tabular}{|l|l|l||}
\hline \multicolumn{2}{|c|}{ ArticleInfo } \\
\hline \hline ArticleID & $:$ & 3792 \\
\hline \hline ArticleDOI & $:$ & $10.1186 /$ gb-spotlight-20001006-03 \\
\hline \hline ArticleCitationID & $:$ & spotlight-20001006-03 \\
\hline \hline ArticleSequenceNumber & $:$ & 229 \\
\hline \hline ArticleCategory & $:$ & Research news \\
\hline \hline ArticleFirstPage & $:$ & 1 \\
\hline \hline ArticleLastPage & $:$ & 2 \\
\hline \hline & & RegistrationDate : 2000-10-06 \\
ArticleHistory & $:$ & OnlineDate $\quad$ 2000-10-06 \\
\hline \hline ArticleCopyright & $:$ & BioMed Central Ltd2000 \\
\hline \hline ArticleGrants & $:$ & \\
\hline \hline ArticleContext & $:$ & 130591111 \\
\hline \hline
\end{tabular}


William Wells

Email:wells@biotext.com

In the 28 September Nature, Altshuler et al. (Nature 2000, 407:513-516) and Mullikin et al. (Nature 2000, 407:516-520) report on the discovery of thousands of single nucleotide polymorphisms (SNPs). These human sequence variants, in which two alternate bases occur at one position, are present at a frequency of up to one per kilobase. A dense map of SNPs would allow certain variants to be associated with disease states. Previous efforts to uncover SNPs have struggled with the effort involved in amplifying specific regions of DNA, or completing several-fold coverage of an entire genome before any SNPs are forthcoming. Altshuler et al. present an alternative technique, in which digested DNA is size-fractionated before being subjected to shotgun sequencing. This method yields over 47,000 SNPs. Mullikin et al. extend the technique by focusing on chromosome 22, and by aligning their sequence data with the completed sequence of this chromosome. In total the SNP consortium of sequencing centers and pharmaceutical companies has now discovered over 350,000 SNPs, of which 250,000 have been mapped to the draft human genome sequence. The SNPs are freely available at the consortium website.

\section{References}

1. Nature, [http://www.nature.com/nature/]

2. Large-scale identification, mapping, and genotyping of single-nucleotide polymorphisms in the human genome.

3. Prospects for whole-genome linkage disequilibrium mapping of common disease genes.

4. The SNP Consortium Ltd., [http://snp.cshl.org]

This PDF file was created after publication. 